\title{
SEA-LEVEL CHANGES AND
}

\section{THEIR EFFECTS}




\section{Also published by World Scientific:}

Computational Techniques and Applications: CTAC93

Proceedings of the Sixth Biennial Conference

Edited by David Stewart, Henry Gardner and David Singleton

Computational Techniques and Applications: CTAC95

Proceedings of the Seventh Biennial Conference

Edited by Robert L May and Alan K Easton

Computational Techniques and Applications: CTAC97

Proceedings of the Eighth Biennial Conference

Edited by John Noye, Michael Teubner and Andrew Gill

Modelling Coastal Sea Processes

Ocean and Atmosphere Pacific: OAP95

Edited by John Noye 
Ocean and Atmosphere Pacific: OAP 95

\title{
SEA-LEVEL CHANGES AND \\ THEIR EFFECTS
}

\author{
Editors \\ John Noye \\ Marcus Grzechnik \\ National Tidal Facility \\ The Flinders University of South Australia \\ Australia
}


Published by

World Scientific Publishing Co. Pte. Ltd.

P O Box 128, Farrer Road, Singapore 912805

USA office: Suite 1B, 1060 Main Street, River Edge, NJ 07661

UK office: 57 Shelton Street, Covent Garden, London WC2H 9HE

\section{British Library Cataloguing-in-Publication Data}

A catalogue record for this book is available from the British Library.

\section{SEAL-LEVEL CHANGES AND THEIR EFFECTS \\ Ocean and Atmosphere Pacific: OAP95}

Copyright $(\mathcal{S} 2001$ by World Scientific Publishing Co. Pte. Ltd.

All rights reserved. This book, or parts thereof, may not be reproduced in any form or by any means, electronic or mechanical, including photocopying, recording or any information storage and retrieval system now known or to be invented, without written permission from the Publisher.

For photocopying of material in this volume, please pay a copying fee through the Copyright Clearance Center, Inc., 222 Rosewood Drive, Danvers, MA 01923, USA. In this case permission to photocopy is not required from the publisher.

ISBN 981-02-3618-2 


\section{Preface}

This book is one of the outcomes of the international Ocean and Atmosphere, Pacific (OAP 95) conference held in Adelaide, South Australia on 23-27 October 1995. The conference was organised by the National Tidal Facility (NTF) of the Flinders University of South Australia, as part of the South Pacific Sea Level and Climate Monitoring Project, funded by AusAID. The aim of the conference was to enhance interaction between local scientists in the South Pacific region and to link regional understanding of climate variability and sea level change to global developments.

Two themes dominated the conference. Firstly, many presentations were concerned with the mathematical modelling of processes which occur in shallow coastal seas and secondly, many papers focused on changes in sea level and their associated effects. After the conference, so much interest was shown in these two areas, that the NTF canvassed delegates who had given outstanding papers, to determine whether they would be prepared to produce extended and updated versions of their presentations for publication in reviewed books, the cost to be borne by the NTF.

The first book to result from this NTF initiative, was published late last year with the title "Modelling Coastal Sea Processes". The present book, titled "SeaLevel Changes and Their Effects", is the second in this series. Articles included in this volume were selected on both their scientific merit and their usefulness to physical oceanographers, marine biologists and coastal developers. They cover a wide range of topics including the effects of longterm sea-level rise on flows in coral lagoons and its impact on mangroves, the determination of long-term sea-level change relative to vertical land movement, to the numerical modelling of short term sea-level changes due to tides and tsunamis and the relative effects of oceanic tides and meteorological events on sea-levels and currents in coastal waters.

The task of organising and editing this volume was carried out by Associate Professor John Noye, who was seconded part-time from the University of Adelaide to do this work. It included getting selected OAP 95 authors to agree 
to participate in the project, organising additional authors where necessary to include important relevant topics which may otherwise have been omitted, arranging for at least two reviews to be received for each article submitted, and getting the authors to modify their articles in the light of the reviewers' reports.

Since his retirement from the University of Adelaide in late 1999, Dr Noye has continued working at the NTF augmenting the tidal modelling group which complements the NTF's expertise in deploying oceanographic instrumentation and archiving and analysing the data collected.

In Dr Noye's absence with illness, the project was taken over by Dr Marcus Grzechnik, an ex-student of Dr Noye's at the University of Adelaide. Marcus is currently employed as a part of the modelling research group at the NTF. His was a significant contribution to the successful completion of this manuscript, acknowledged by inclusion as co-editor.

Wolfgang Scherer Director, NTF 


\section{Acknowledgements}

We wish to thank Ms Di Paech, who typed the reams of correspondence involved in soliciting articles for this book and obtaining at least two reviews of each submitted manuscript. We are also grateful to James Chittleborough and Darrell Strauss for their help in preparing and modifying diagrams, and Kerry Spriggs for her thorough proof-reading and constructive comments. We must also thank the contributors to this book, all of whom spent a great deal of time preparing and modifying their manuscripts, and the 43 referees who assessed the merit of the articles submitted and wrote the associated reports.

John Noye Marcus Grzechnik

Editors 
This page is intentionally left blank 


\section{Contents}

Preface $\ldots \ldots \ldots \ldots \ldots \ldots \ldots \ldots \ldots \ldots \ldots \ldots \ldots \ldots, \mathbf{v}$

Acknowledgements $\ldots \ldots \ldots \ldots \ldots \ldots \ldots \ldots \ldots \ldots \ldots$ vii

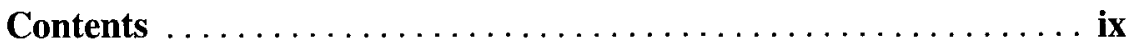

1 Sea-Level Change in the Pacific

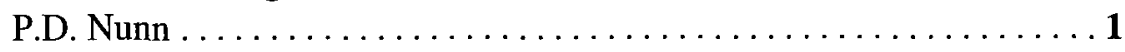

2 Effects of Sea-Level Rise on the Hydrodynamics of a Coral Reef Lagoon: Kaneohe Bay, Hawaii C.J. Hearn , M.J. Atkinson . . . . . . . . . . . . . . . . . . . . 25

3 Possible Impacts of Predicted Sea-Level Rise on South Pacific Mangroves

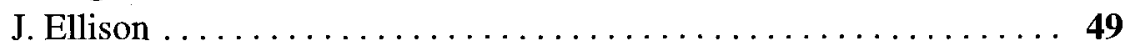

4 Monitoring Sea Level: Who's monitoring the Land?

S.M. Turner, G.M. Homes . . . . . . . . . . . . . . . . . . 73

5 Relative Sea-Level Change and Geologic Corrections to South Australian Tide Gauge Records

E.J. Barnett, N. Harvey .......................... 95

6 Low Frequency Sea Level Variability in the Western Tropical Pacific 1992-1998

J-M. Verstraete . 
7 An Analysis of Variance in Pacific Tide Gauge Data J.L. Luick .................................. 215

8 Hindcast Modelling of Recent Tsunamis in the Australian Region W.M. Mitchell, J.B. Chittleborough and B.J. Noye ........... 241

9 Adaptation Policies-Addressing Climate Change Impacts in the Pacific Region C. Kaluwin ................................ 273

Index $\ldots \ldots \ldots \ldots \ldots \ldots \ldots \ldots \ldots \ldots \ldots \ldots \ldots \ldots, \ldots \ldots$ 